\title{
DESIGN OF AN EXPERT INFORMATION SYSTEM FOR DECISION-MAKING IN THE TEXTILE INDUSTRY
}

\author{
Goicoechea Castano, I. \& Pelaez Lourido, G.
}

Abstract: The overarching goal of this study is to create an expert information system for decision-making in the textile industry.

The goal is to create a decision-making model based on "Knowledge Engineering":

o Knowledge of the design of a new product

o Knowledge of the current manufacturing process

o Knowledge of how the machinery currently operates

o Knowledge of the machinery's flexibility

o Knowledge of machine times

Key words: Knowledge Management, expert system
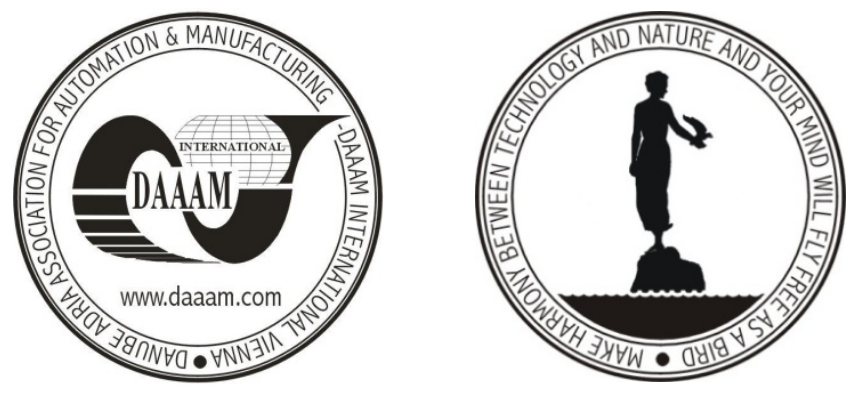

Authors' data: Dr. Eng. Goicoechea Castaño, I[tziar $]^{*} ;$ Ph D. Eng. Pelaez Lourido, G[ustavo]** , *University of Vigo, Camiño de ferro $\mathrm{n}^{\circ} 7-2^{\circ}$ b-, 36003, PONTEVEDRA, ES, **ETSEI. Campus Lagoas-Marcosende 36200 Vigo-Spain, igoicoechea@uvigo.es,gupelaez@uvigo.es

This Publication has to be referred as: Goicoechea Castano, I[tziar] \& Pelaez Lourido, G[ustavo] (2008). Design of an Expert Information System for DecisionMaking in the Textile Industry, Chapter 27 in DAAAM International Scientific Book 2008, pp. 317-324, B. Katalinic (Ed.), Published by DAAAM International, ISBN 978-3-901509-66-7, ISSN 1726-9687, Vienna, Austria

DOI: $10.2507 /$ daaam.scibook.2008.27 